\title{
SCIENTIFIC CIVIL SERVICE PROMOTION OF INDIVIDUAL RESEARCH WORKERS
}

$\mathrm{S}^{\mathrm{p}}$ PECIAL posts have again been created this year in the Scientific Civil Service under provisions included in the White Paper (Cmd. 6679; 1945) designed to provide for the promotion of individual research workers of exceptional merit. The promotions are effective from July $I$.

\section{Deputy Chief Scientific Officers}

DR. S. K. KoN, who has been head of the Nutrition Department of the National Institute for Research in Dairying since 1937, has made extensive researches which have led him to be recognized both nationally and internationally as a leading authority in nutritional science. In particular, his work has covered the nutritive value of milk and milk products, methods of assay of vitamins (especially vitamin A and the $B$ vitamins) and the synthesis of vitamins in the animal organism, and this and studies in several other fields of nutritional biochemistry have provided both new knowledge and valuable practical applica. tions. He has been editor of the Proceedings of the Nutrition Society since the inception of that Society in 1944 and of the British Journal of Nutrition from its beginnings in 1947.

DR. H. R. C. Pratr studied chemistry at Birkbeck College, London, and, later on, chemical engineering, his Ph.D. thesis in 1951 on "Studies in Azeotropic Distillation" being based on work done during the Second World War. He held research and development appointments in industry before joining the Atomic Energy Research Establishment, Harwell, in 1949 as leader of a group investigating chemical engineering operations of special interest to atomic energy. Dr. Pratt has himself made a significant contribution to liquid-liquid extraction and for one of bis published papers he was awarded, with $R$. Murdoch, the Moulton Medal of the Institution of Chemical Engineers last year. $\mathrm{He}$ is also interested in the methods of production of heavy water, and his developments in water distillation techniques have brought this method into the realm of practical economics.

\section{Senior Principal Scientific Officers}

Dr. H. A. H. Воот graduated from the University of Birmingham in 1938 and later, during the Second World War, was co-inventor, with Dr. J. T. Randall, of the cavity magnetron which established and maintained for the Allies so great an advantage in the field of radar. During 1945-48 Dr. Boot held a senior Nuffield research fellowship at Birmingham and was engaged on the design of the cyclotron. He then joined the Royal Naval Scientific Service and since then has been mainly occupied at the Services Electronics Research Laboratory in research, development and design for the manufacture of advanced types of magnetron of very high power.

Mr. K. V. Diprose entered the Royal Aircraft Establishment in 1935 on leaving Cambridge, where he had read for the Mechanical Sciences Tripos, being awarded the J. B. Seeley Prize in Aeronautics. $\mathrm{He}$ has displayed outstanding scientific and design ability in several fields, including the instrumentation of wind tunnels, the aerodynamies of airscrews, early jet-engine research, analogue computing instruments and data-reduction schemes for wind tunnels. He is a leading British authority on analogue computers, and the present general recognition of the importance of a co-ordinated approach to the whole problem of the design of experiments, processing of data and computing of results, is due in large measure to his efforts during the past ten years.

Mr. T. M. FRY worked on underwater detection problems for the Admiralty during 1939-45, before proceeding to the University of Cambridge. After graduating in 1947, he joined the Atomic Energy Research Establishment, Harwell, where he investigated changes in the properties of graphite and other solids resulting from exposure to the radiations in nuclear reactors. As well as its importance for the development of nuclear power, this type of work provides a new method for investigating the solid state. Since 1951 he has devoted his attention mainly to a study of the fast-breeder reactor, and in addition, since 1947, he has been associated with Mr. F. T. Bacon's hydrogen-oxygen cell research at Cambridge.

DR. E. R. R. Holmberg graduated from the University of Cambridge in 1939 and entered Admiralty service the following year. He was appointed to the Mine Design Department and during the next five years played a significant part in solving the many problems involved in ship demagnetization. In 1945 he was transferred to the Admiralty Gunnery Establishment, where his mathematical ability was directed to theoretical studies of missile guidance and control systems. Since 1950 he has been serving in the Department of Operational Research. In 1952 he was elected to the Geophysical Committee of the Royal Astronomical Society and has had a number of papers published in the Monthly Notices of the Society in which, as in his defence research work, he has shown a marked originality of outlook and incisiveness of method.

DR. D. KÜCHEMANN was engaged in aeronautical research at A.V.A. Göttingen with Prof. Betz after obtaining his doctorate at the University of Göttingen in 1936. He gained a considerable reputation there for his work on basic aerofoil theory, wind-tunnel corrections and the aerodynamics of propulsion. He joined the Royal Aircraft Establishment in 1946 in the Wind Tunnels Group, where he has made important contributions to research on swept wings and the flow about high-speed aircraft configurations, both from the theoretical and experimental aspects, which have led to a greatly improved understanding of the fundamentals of high-speed aircraft design.

MR. S. W. Noble joined the Telecommiunications Research Establishment, now the Radar Research Establishment, at Swanage in 1940, after varied industrial experience. He was engaged on research in the radar field until 1944, when he commenced work on advanced circuit research with which his name is now prominently associated. He has made outstanding and distinctive contributions to electronic circuit design, in which field he is an acknowledged leading authority.

Dr. F. PASQuill has been mainly engaged in problems of atmospheric diffusion and turbulence 
near the surface of the earth, since his appointment to the Meteorological Office in 1937. His association. with the Chemical Defence Experimental Establishment, Porton, during his early years of service, was marked by a valuable experimental study of evaporation from a plane-free liquid surface into a turbulent air stream. Later, in charge of a small Meteorological Office group attached to the School of Agriculture, Cambridge, to study micro-meteorological problems with application to agriculture, he devised a method and equipment for the investigation (by the use of accurate vertical profile measurements of humidity and temperature) of the exchango of heat and water vapour between a grass-covered surface and the air immediately above. This led to a successful evaluation of evaporation from the surface. The aerodynamic drag of grassland was also investigated. Dr. Pasquill is now engaged in research on atmospheric diffusion processes on a more extended scale.

DR. J. M. SHewan studied chemistry in the University of Aberdeen, being awarded a medal in physical chemistry in 1932, and gained his Ph.D. for work at the Macaulay Soil Research Institute. $\mathrm{He}$ then entered on a career in marine bacteriology and biochemistry at the Torry Research Station, where his work has included the only really detailed study of the strict anaerobes of fish, a survey of the aerobic microflora of gadoids, and the discovery that the microflora of fish varies considerably with species, locality, time of year and method of catching. In the preservation of fish he has shown how the microflora changes in composition, as spoilage proceeds, and he has made pioneering studies of the effect of phenolic substances in wood smoke in the curing of smoked fish. $\mathrm{He}$ is at present engaged in unravelling the taxonomic confusion which exists in the field of marine bacteriology, and on an extensive study of the extractives of fish which are the substances first attacked by bacteria. In connexion with the preservation of fish on ice, he has developed a sensory scoring system which, as a research tool, has become of great use in defining and controlling standards of freshness.

Mr. G. W. C. TAYlon joined the Research Department, Woolwich Arsenal, in 1929, transferring to the staff of the Explosives Research and Development Establishment, Waltham Abbey, on its formation in 1945. His early experience was in the chemical analysis and testing of explosives, which was followed by photographic and radiological investigations. Since 1939 he has been concerned with a special class of explosives, carrying his researches from the laboratory stage to full-scale manufacture, and this has led to investigations on the control of crystallization which have given rise to practical results of the greatest value. Much of his work has been of a pioneering nature in a region hitherto unexplored because of the formidable hazards and difficulties involver.

Mr. J. H. WILKINSON graduated in mathematics from the University of Cambridge and then worked on ballistics in the Ministry of Supply for some six years bofore joining, in 1946, the Mathematies Division of the National Physical Laboratory, 'Teddington. He has worked on the design and exploitation of high-speed automatic electronic digital computers, and has been very closely associated with the theoretical design, electronics and practical use of the Laboratory's machine, the Pilot ACE. In particular, he has made a very thorough study of practical methods of ealculating latent roots and vectors of matrices, which are of wide application, especially in problems of aircraft design.

Dr. H. G. Wolfrard studied physics at the University of Göttingen, gaining his doctorate in 1938, and later joined L.F.A. Volkenrode, where he worked until 1946, taking charge of a group on combustion towards the end of this period. He joined the Royal Aircraft Establishment in the same year, where he has worked in the Chemistry Department and, more recently, in the Rocket Propulsion Depart:ment in charge of the combustion section. During 1946-52 he worked part-time with Dr. A. G. Gaydon at the Imperial College of Science and Technology, London. He has been outstandingly successful in the application of spectroscopy to the study of flames and combustion processes.

\section{WORLD POWER RESOURCES}

TN his presidential address given before the 1 Institution of Electrical Engineers on October 7, Mr. J. Eccles was concerned mainly with the power resources of the world. He skotched in outline the origins of the earth's main resources of fuel, first tracing the exceedingly gradual evolution of man's use of mechanical power up to the opening of the industrial era. He then showed that, with the enormously accelerated rate of consumption of fuel which has developed during the past two hundred and fifty years, a further period of several hundred years will see the substantial exhaustion of the world's resources of coal and oil ; indeed, the supply of oil fuel may well become critical during the lifetime of the present rising generation.

Dealing with other available forms of energy, apart from nuclear energy, Mr. Eccles first considered water power and tidal power. Some forty per cent of the world total of inland water power is located in Africa, and this total without, of course, regard to location, could supply at least three-quarters of the world's present energy requirements. He remarked that one of the largest and most spectacular sources of water power lies at the western end of the Mediterranean, for this inland sca loses water through evaporation at a rate exceeding its river inflow, so that water is constantly flowing through the Straits of Gibraltar and, to a lesser extent, through the Dardanelles. If both straits wore dammed, the level of the Mediterranean would gradually fall, and rough calculation shows that, having established a differential of $70 \mathrm{ft} ., 12$ million $\mathrm{kW}$. (which is 75 per cent of the present demand for electricity in (Great Britain) could be developed from suitable turbines operated by inflow from the Atlantic.

Summing up the position in regard to what may be termed the conventional sources of energy, Mr. Eccles said that, when coal and oil are exhausted, and in the absence of a succossful outcome of the attermpts to harness the nuclear fission or fusion process for industrial purposes, it should be possible to muster man's present-day energy requiremonts from all the known sources, but that energy transmission or population transportation would present enormous technical and social problems.

If the present pattern of civilization is to endure, the problems of nuclear energy must be mastered. It has been established, said Mr. Eccles, that, on the basis of present costs, an expenditure of about 